\title{
State Sovereignty and Nuclear Free Zones
}

\author{
Luis Li†
}

Nuclear free zone ordinances present courts with choices between local and national interests and between judicial and legislative decisionmaking. This Comment argues that courts should not forbid state and local governments from using traditional police powers to ban the manufacture of nuclear weapons and weapons parts within their borders. First, the Constitution does not prohibit nuclear free zones. The federal interest in foreign affairs is not so broad as to invalidate all state or local action affecting this field. The Supreme Court has allowed state action indirectly affecting foreign affairs. Properly constructed nuclear free zones fall within this area. Second, Congress has not manifested its intent to occupy the entire field of nuclear weapons production. The Supreme Court has favored state and local interests by requiring Congress to make clear its intent to preempt state regulation of nuclear materials. Where no such intent is clear, economic decisions of local concern have been left to local choice. Third, nuclear free zones do not conflict with federal statutes or obstruct federal purposes. The Supreme Court has found that the development of nuclear technology was not intended to proceed at all costs. The costs of nuclear free zones are low-it is unlikely that every community will enact nuclear free zones, and even were every community to do so, the federal government could still continue production in its own facilities. Finally, nuclear free zones raise the question of whether the Supreme Court should invent congressional intent in its absence. In developing contemporary federalism, the Court has emphasized its preference for state interests and its reluctance to presume exclusive federal powers. Were the Supreme Court to pursue the logic of its recent decisions, no bar should exist to limited nuclear free zones that are narrowly tailored, based upon legitimate local concerns, and economically justified. The author concludes that communities are free to exercise their police powers to prohibit the local manufacture of nuclear weapons.

$\dagger$ B.A. 1987, Yale University; J.D. 1991, Boalt Hall School of Law, University of California, Berkeley. I would like to thank Jennifer Lee and John Coltrane. 
INTRODUCTION

On August 20, 1990, the United States District Court for the Northern District of California found unconstitutional a municipal ordinance making Oakland, California, a nuclear free zone. ${ }^{1}$ The ordinance prohibited any person from knowingly engaging in "nuclear weapons work."2 Nuclear weapons work was defined as "any work that has as its purpose the development, testing, production, possession, nuaintenance or storage of nuclear weapons, the components of nuclear weapons, or any secret or classified research or evaluation of nuclear weapons."3

The ordinance further restricted the transportation of "nuclear weapons or other hazardous radioactive materials" through Oakland, ${ }^{4}$ and prohibited any person from reprocessing, storing, dumping, or using "hazardous radioactive materials" within Oakland.5 Oakland was also prohibited, with certain exceptions, from contracting with or investing in any person or company "knowingly engaged in nuclear weapons work," or with their "agent, subsidiary or parent organization." To enforce its provisions, the ordinance included civil ${ }^{7}$ and criminal penalties. ${ }^{8}$ It also required persons engaged in nuclear weapons work to submit annual reports describing those activities and the "steps being taken to cease such activities within two years" of the ordinance's passage."

Finding "[t]he Ordinance taken as a whole is so comprehensive, so complete, so all-encompassing that it cannot help but conflict with the rights and authority of the federal government," District Judge Vukasin mvalidated thc Oakland nuclear free zone. ${ }^{10}$ The court based its decision on two separate grounds. First, the ordinance "violat[ed] . . . the War Powers Clauses of the United States Constitution." "11 The court agreed with the City of Oakland that the "Ordinance's interference with the federal government may be sinall relative to the global extent of defense

1. United States v. City of Oakland, No. C-89-3305 JPV 13-14 (N.D. Cal. Aug. 20, 1990) (opinion and order granting plaintiff's notion for partial summary judgment) (invalidating Oakland, Cal., Ordinance 11,062 (Dec. 16, 1988)). For a more detailed examination of both the ordinance and the opinion, see Note, The Constitutionality of Oakland's Nuclear Free Zone Ordinance, 18 HASTINGS CoNST. L.Q. 189 (1990).

2. Oakland, Cal., Ordinance $11,062 \S 4$ (Dec. 16, 1988).

3. Id. § 11(d).

4. Id. $\S 5$.

5. Id. $\S 6$.

6. Id. $\S \S 7,11$.

7. Id. $\S 10(\mathrm{e})$ (giving residents right to enforce the ordinance by civil action for declaratory or injunctive relief).

8. Id. $\S 10(f)$ (punishing violations with maximum penalty for a misdenieanor).

9. Id. $§ 10(\mathrm{~b})(\mathrm{i})$-(ii).

10. United States v. City of Oakland, No. C-89-3305 JPV $4-5$ (N.D. Cal. Aug. 20, 1990) (opinion and order granting plaintiff's motion for partial summary judgment).

11. Id. at 13 . 
operations," and that "no one would argue that Oakland's ordinance, in and of itself, poses an insurmountable risk to national security." $12 \mathrm{Nev}$ ertheless, the court found the ordinance so broad that it "clearly interfere[d] with United States defense policy directly and substantially."13 Second, the court found the ordinance preeinpted by federal legislation. According to the court, the Hazardous Materials Transportation Act preenipted the sections of the ordinance that regulated the transportation of nuclear weapons or other hazardous nuclear materials. ${ }^{14}$ Finally, the Atomic Energy Act ("AEA") preeinpted the ordinance's regulation of "military applications of atomic energy." 15

The decision of the district court has been appealed to the United States Court of Appeals for the Ninth Circuit. ${ }^{16}$

Nuclear free zones challenge courts to articulate the relationship between federal and state governments in the area of foreign relations. Altliougl the Constitution empowers only the federal government to conduct foreign affairs and national defense, it is not clear what level of "exclusivity" this deniands. Does, as Judge Vukasin appears to hold, the Constitution forbid any state action that influences federal nuclear policy? Would this prohibition extend to, for instance, a city ordinance aimed at reducing traffic in school zones that limited commercial trucks, including those carrying nuclear weapons parts, to certain routes? Further, Judge Vukasin's opinion failed to explain exactly how the AEA preempts nuclear free zones. The AEA clearly grants the federal governinent expansive power in the area of nuclear weapons. ${ }^{17}$ Yet, does the AEA disallow all nuclear free zones regardless of their scope? This Comment will argue that certain limited nuclear free zones may withstand constitutional and statutory preemption challenges.

As of Marcli 1990, there were over 165 nuclear free zones in the Umited States and over 170 nuclear free zone canpaigus underway. ${ }^{18}$ The regulatory scope of nuclear free zones ranges from Oakland's broadly restrictive ordinance to laws expressing only symbolic protest against federal nuclear policy. ${ }^{19}$ Nuclear free zones are vulnerable to judicial challenge because they may interfere with the federal govern-

\section{Id. at 9.}

13. Id.

14. Id. at 11-13 (citing Hazardous Materials Transportation Act, 49 U.S.C. $\S \S 1801-1813$ (1988)).

15. Id. (citing Atomic Energy Act of 1954, 42 U.S.C. §§ 2013(c), 2021 (1988)).

16. Appellants' Opening Brief, United States v. City of Oakland, No. 90-16538 (9th Cir. filed February 14, 1991) (on file with the author). The City of Oakland itself has not appealed, but the nonprofit organization that sponsored the initiative that resulted in the ordinance has appealed as an intervenor. See id. at 2.

17. See Atomic Energy Act of 1954, 42 U.S.C. $\S$ 2011-2296 (1988).

18. The New Abolitionist, Mar. 1990, at 12.

19. See id. 
nent's military policy and foreign affairs. As Judge Vukasin's opinion argued, the Constitution may prohibit or statutes may preenipt state and local laws that conflict witl these substantial federal interests. The current trend in the Supreme Court's statutory preeniption doctrine, lowever, is favorable to nuclear free zones because the Court defers to state interests. To survive botll constitutional and statutory cliallenges, nuclear free zones must be narrowly tailored and must be based on legitimate local concerns that do not substantially encroach upon exclusive federal interests. Nuclear free zone ordinances prohibiting only the private manufacture of nuclear weapons and resting on economic justifications are most likely to survive judicial scrutiny. ${ }^{20}$

This Comment will focus on this type of narrowly tailored ordinance and will suggest low such limited nuclear free zones may withstand challenge under the Supreme Court's current constitutional and statutory preeunption doctrines. Part II will explore the federal government's constitutionally based "dormant foreigu affairs" power and will conclude that a nuclear free zone only indirectly affecting military powers and foreign affairs may be upleeld. Part III will demonstrate that current trends in the Court's statutory preeniption doctrine favor nuclear free zones, emphasizing two recent cases involving nuclear power, Pacific Gas \& Electric Co. v. State Energy Resources Conservation \& Development Commission ${ }^{21}$ and Silkwood v. Kerr-McGee Corp. ${ }^{22}$ Part IV will conclude that nuclear free zones based on legitimate economic concerns may not be preeinpted by the AEA. ${ }^{23}$

20. This Commeut adopts a definition of nuclear weapon which includes the weapon's guidance system, triggering device, and other component devices, provided that the system or device is destroyed during the normal use of the weapon.

21. 461 U.S. 190 (1983).

22. 464 U.S. 238 (1984).

23. 42 U.S.C. $\$ \S 2011-2296$ (1988). This Comment will not address possible commerce clause objections to nuclear free zones because the courts themselves have declined to discuss this constitutional doctrine. Since there are federal statutes governing nuclear weapons, preemption claims constitute the inost appropriate approach for a challenge to a nuclear free zone. As a result, most cases involving nuclear power or nuclear free zones focus only on preemption issues. See, e.g., Silkwood v. Kerr-McGee, 464 U.S. 238 (1984); Pacific Gas \& Elec. Co. v. State Energy Resources Conservation \& Dev. Comm'n, 461 U.S. 190 (1983); United States v. City of Oakland, No. C-893305 JPV (N.D. Cal. Aug. 20, 1990) (opinion and order granting plaintiff's motion for partial summary judgurent); Fossella v. Dinkins, 110 A.D.2d 227, 494 N.Y.S.2d 878, aff'd, 66 N.Y.2d 162, 485 N.E.2d 1017, 495 N.Y.S.2d 352 (1985). Further, given the Court's preference for interpretimg existing statutes rather than creating constitutional law, shonld the Court decide to invalidatc a nuclear free zone, preemption would be the preferred ground. See generally Comment, Preemption as a Preferential Ground: A New Canon of Construction, 12 STAN. L. REv. 208 (1959) (discussing criticisms of Supreune Court's preemption doctrine). 
II

\section{Constitutional Preemption: Federal Supremacy in FOREIGN AFFAIRS}

The Constitution grants to the federal government exclusive power to regulate military and foreign affairs. ${ }^{24}$ Specifically, this constitutional grant empowers the federal government to declare war and to create, maintain, and govern the armed forces. ${ }^{25}$ In support of federal exclusivity in these areas, the Constitution forbids the states from declaring war or keeping troops or other instrumentalities of war without congressional consent. ${ }^{26}$ The Constitution also grants the federal government the power to conduct foreign affairs. Thus, the federal government may regulate commerce with foreign nations, grant letters of marque and reprisal, make treaties, and appoint ainbassadors. ${ }^{27}$ The Constitution also forbids the states from entering into treaties with foreign nations, or granting letters of marque or reprisal. ${ }^{28}$

The Frainers gave the federal government these powers because they reasoned that centralized authority would best provide for "the common defence of the members; the preservation of public peace, as well against internal convulsions as external acts; the regulation of commerce with other nations and between the States; the superintendence of our intercourse, political and commercial, with foreign countries."29 As James Madison argned: "If we are to be one nation in any respect, it clearly ought to be in respect to other nations." 30

Significantly, neither the Constitution nor the Framers distinguished between military matters and foreign affairs. Indeed, the text of the Constitution consistently collapses the two areas. ${ }^{31}$ Both powers require centralized federal authority. Nor has the Supreme Court articulated different standards in evaluating the effects of state action on foreign affairs and military matters. Both are areas of exclusive federal interest. ${ }^{32}$

24. See generally L. Henkin, Foreign AfFatrs AND the ConstrTUtion chs. I, IX (1972) (discussing constitutional authority of federal government in foreign affairs and examining states' role in foreign affairs).

25. U.S. CoNsT. art. I, § 8, cls. 11-16.

26. Id. \& 10, cl. 3.

27. Id. § 8, cls. 3, 11; id. art. II, § 2, cl. 2.

28. Id. art. I, $\S 10$, cls. $1,3$.

29. The Federalist No. 23, at 142 (A. Hamilton) (S. Mittell ed. 1961). See also id. Nos. 3-5, 24-29, 41-42, 80.

30. Id. No. 42 , at 270.

31. See, e.g., U.S. CoNST. art. I, § 8, cl. 11 (empowering federal governinent to "declare War, grant Letters of Marque and Reprisal, and make Rules concerning Captures on Land and Water"); id. $\S 10, \mathrm{cl} .1$ (prohibiting states from "enter[ing] into any Treaty, Alliance, or confederation"); id. cl. 3 (prohibiting states, without Congress' consent, from "keep[ing] Troops, or Ships of War in time of Peace" and "enter[ing] into any agreement or Compact with another state, or with a foreign Power").

32. See, e.g., Chinese Exclusion Case, 130 U.S. 581, 606 (1889) ("For local interests the several 
As a result, commentators often equate foreign affairs and military matters and treat them as analogous interests. ${ }^{33}$ The following discussion adopts this analytical posture.

Although the Constitution clearly grants the federal government exclusive power in the area of foreign and military affairs, the boundaries of this exclusivity are not precise. Does, for instance, the Constitution forbid state action that in any way affects foreign affairs? Or must the state action affect foreign affairs in some significant and measurable way before the Constitution requires its displacement? Measuring how inuch a state law does and may affect foreign affairs is unscientific at best, but the Supreme Court has articulated some useful factors. This Comment suggests that the Court distinguishes between state action that directly affects foreign affairs and state action that indirectly affects foreign affairs. While the former is impermissible, the Constitution allows the latter. Simce limited nuclear free zones only indirectly affect military policy and foreign affairs, they should withstand a constitutional preemption challenge.

\section{A. State Regulations Directly Affecting Foreign Affairs}

The Supreme Court's preemption of state actions directly affecting the military provides the strongest example of the "dormant foreign affairs clause." In the first landmark decision, Tarble's Case, ${ }^{34}$ the Court demied state courts the power to issue writs of habeas corpus to release soldiers held in federal custody. ${ }^{35}$ The Wisconsm Supreme Court had affirmed the issuance of a writ of habeas corpus to free Edward Tarble, an enlisted soldier held in federal custody who alleged that he was a mimor and had enlisted without his father's consent. ${ }^{36}$

In reversing the Wisconsin court, the Supreme Court noted at the outset the "distinct and independent character of the government of the United States, from that of the government of the several States."37 Given the two governments' imdependent spheres of action, it followed that "neither can intrude ... into the domam of the other, except so far as such intrusion may be necessary on the part of the national govern-

States of the Union exist, but for national purposes, embracing our relations with foreign nations, we are but one people, one nation, one power."); Tarble's Case, 80 U.S. (13 Wall.) 397, 408 (1871) ("No interference with the execution of th[e] power of the National government in the formation, organization, and government of its armies by any State officials [can] be permitted.").

33. See Borchers \& Dauer, Taming the New Breed of Nuclear Free Zone Ordinances: Statutory and Constitutional Infirmities in Local Procurement Ordinances Blacklisting the Produccrs of Nuclear Weapons Components, 40 HASTINGS L.J. 87, 110-11 (1988); Comment, The Legality of Nuclear Free Zones, 55 U. ChI. L. REv. 965, 973-79, 991-97 (1988).

34. 80 U.S. (13 Wall.) 397 (1871).

35. Id. at 408-09.

36. Id. at 398,400 .

37. Id. at 406 . 
ment to preserve its rightful supremacy."38 The Court then reasoned that because the Constitution had assigned to the national government the power " 'to raise and support armies,' and the power 'to provide for the government and regulation of the land and naval forces," "the power of the federal government in these areas was "plenary and exclusive." 39

Tarble's Case demonstrated an extreme apphication of what one commentator has called "constitutional preclusion." 40 Envisioning the relationship between the federal government and the states as one of distinct and independent spheres, the Court reasoned that the Constitution's enumeration of the federal power to raise and support armies entirely excluded the states from any action in that field. ${ }^{41}$ No federal statute was at issue. The Court merely cited two foreign affairs clauses governing military power and then ruled the state action unconstitutional. ${ }^{42}$

The Court has recently reaffirmed the view that the federal government has exclusive control where state action directly affects military power. In Perpich v. Department of Defense, ${ }^{43}$ the Court relied on article I of the Constitution to hold that Congress could order members of the National Guard of the United States to active duty outside the country without the state governor's consent. By federal statute, all persons who enlist in a State National Guard unit simultaneously enlist in the National Guard of the United States. ${ }^{44}$ Until 1985, State Guards could not be ordered to federal duty unless there was a national emergency or the state governor consented. ${ }^{45}$ In 1986, however, Congress passed the Montgoniery Amendment which prohibited state governors from withholding consent. ${ }^{46}$

The Governor of Minnesota challenged this amendment. He argued that the militia clauses of the Constitution grant to the states the exclusive responsibility for nonenergency training of state militia. ${ }^{47}$ As a result, the Governor argued, the Montgomery Amendment impermissibly withdrew state control of training in nonenergency situations. ${ }^{48}$

38. Id. at 407 .

39. Id. at 408 (quoting U.S. ConsT. art. I, $\S 8$, cls. 12, 14).

40. See Comment, supra note 33, at 973-79 (discussing cases in which courts have invalidated state regulations affecting defense and foreign affairs on grounds that those are areas of exclusive federal power).

41. Tarble's Case, 80 U.S. at 408.

42. Id.

43. 110 S. Ct. 2418 (1990).

44. Id. at 2425 .

45. Id. at $2420-21,2425-26$.

46. Id. at 2420-21, 2426. The amendment was enacted after the Governors of California and Maine refused to send State Guards to training missions in Honduras in 1985. Id. at 2426.

47. Id. at 2421, 2427. Clauses 15 and 16 of article I, section 8 of the Constitution are considered the "Militia Clauses." Id. at 2421 n.3.

48. Id. at $2421,2426$. 
Writing for the majority, Justice Stevens rejected the Governor's arguinents and held that State Guard members lose their state status when called to active federal duty. ${ }^{49}$ As a result, if that duty involves training, the training is performed by the federal army. ${ }^{50}$ Justice Stevens' analysis relied on the Selective Draft Law Cases, ${ }^{51}$ which held that the militia clauses do not constrain Congress' article I powers to provide for the common defense, raise and support armies, make rules for the governance of the Armed Forces, and enact necessary and proper laws for such purposes. ${ }^{52}$ Finally, Justice Stevens concluded that the Court's lolding did not eviscerate the militia clauses, but rather "merely recognize[d] the supremacy of federal power in the area of military affairs." 53

Although Perpich did not imvolve state legislative action, it clearly limits the states' role im the area of military affairs. As in Tarble's Case, the Court justified its decision by relying almost entirely on the foreign affairs clauses governing military affairs. ${ }^{54}$ Although neither case articulated its holding in terms of a "dormant foreigu affairs" power, they stand for the general proposition that the Constitution itself may preclude state action in areas directly affecting military affairs.

One state court has reached the saine conclusion in a case involving nuclear weapons. In Fossella v. Dinkins, ${ }^{55}$ the New York Court of Appeals addressed the validity of a referendum to annend the New York City charter. The ainendinent would have prohibited the city from "consenting to the use of city-owned property for the development of any military facility at which nuclear weapons are to be deployed."56 The referendum was aimed at an agreement between the Navy and New York City to station warships at Staten Island. ${ }^{57}$

Although the New York Court of Appeals never reached the constitutional preemption issue, ${ }^{58}$ both the New York Appellate Division and the New York Supreine Court addressed the preeinption issue and struck the proposed referendum from the ballot. ${ }^{59}$ Both courts found that the

49. Id.

50. Id.

51. 245 U.S. 366 (1918).

52. Perpich, 110 S. Ct. at 2427 (citing Selective Draft Law Cases, 245 U.S. 366, 375, 377, 38184 (1918)).

53. Id. at 2428.

54. See id. at 2429.

55. 66 N.Y.2d 162, 485 N.E.2d 1017, 495 N.Y.S.2d 352 (1985).

56. Fossella v. Dinkins, 110 A.D.2d 227, 228, 494 N.Y.S.2d 878, 879 (App. Div. 1985).

57. Fossella v. Dinkins, 128 Misc. $2 d$ 822, 830, 493 N.Y.S.2d 947, 953 (N.Y. Sup. Ct. Spec. Term 1985).

58. Never reaching the constitutional issue, the New York Court of Appeals invalidated the referendum on the basis of state municipal corporation law. Fossella, 66 N.Y.2d at 167, 485 N.E.2d at 1018-19, 495 N.Y.S.2d at 353-54.

59. Fossella, 110 A.D.2d at 229-31, 494 N.Y.S.2d at 880; Fossella v. Dinkins, 130 Misc. 2d 52, 56, 494 N.Y.S.2d 1012, 1017 (Sup. Ct. 1985). 
referendum would impermissibly conflict with the federal government's national defense responsibilities. ${ }^{60}$ The appellate division reasoned that if local governments "were given the power to restrict the establishment and operation of Federal military installations or weaponry located withm [their] jurisdiction[s], the power of the Federal government to raise and maintain an army and navy would . . . be destroyed."61

The opimons did not discuss federal statutes. The holdings instead rehed solely on the federal government's constitutional power to " 'raise and support Armies ... [t]o provide and maintain a Navy [and] [t]o make Rules for the Government and Regulation of the land and naval Forces." "62 Like the Supreme Court in Tarble's Case, ${ }^{63}$ the New York Appellate Division in Fossella v. Dinkins cited an enumerated power and then adopted an extremely broad subjeet matter approach to preemption. These cases suggest that there are no local interests that could jnstify local regulations directly affeeting the military or the stationing of military personnel, equipment, or weapons. ${ }^{64}$

In the most recent Supreme Court case involving a state law that directly affeeted federal military interests, however, the Court was not so absolute. In Boyle v. United Technologies Corp., ${ }^{65}$ the Court considered whether government defense contractors could be held hable under state tort law for design defects. The Court found that imposing such hability would "directly affeet the terms of Government contracts: either the contractor will decline to manufacture the design specified by the government, or it will raise its price." ${ }^{\prime 66}$ However, the Court only preempted state tort law where "(1) the Uinted States approved reasonably precise specifications; (2) the equipment couformed to those specifications; and (3) the suppher warned the Umited States about the dangers in the use of the equipment that were known to the supplier but not to the United States."67 It did not preeinpt hability under state tort law for design defects where the government purchased standard military equipment from stock and had not specified a particular design. ${ }^{68}$

Thus, the Court narrowly tailored its holding to proteet ouly the

60. Fossella, 110 A.D.2d at 229-31, 494 N.Y.S.2d at 880; Fossella, 130 Misc. 2d at 56, 494 N.Y.S.2d at 1017.

61. Fossella, 110 A.D.2d at 230, 494 N.Y.S.2d at 880.

62. Id. at 229, 494 N.Y.S.2d at 880 (quoting U.S. CoNST. art. I, § 8, cls. 12-14).

63. 80 U.S. (13 Wall.) 397 (1871). For a discussion of Tarble's Case, see supra text accompanying notes $34-40$.

64. See Comment, supra note 33, at 968-70, $973-79$ (discussing progression of Fossella v. Dinkins through New York courts and "constitutional preclusion" as a basis to invalidate local regulation of defense-related activities).

65. 487 U.S. 500 (1988).

66. Id. at 507 .

67. Id. at 512 .

68. Id. at $510-12$. 
federal government's interest in procuring weapons that it specifically designs or approves, and not to protect a broader federal interest in general weapons procurement. Because imposition of liability for neghigence is a form of regulation, ${ }^{69}$ Boyle implies that, under certain circumstances, state regulation of defense contractors is permissible. Thus, the federal interest in weapons procureinent is not absolute, and state law based on legitimate state interests inay survive if the infringement upon weapons procurement is not too debilitating.

\section{B. State Regulation Indirectly Affecting Foreign Affairs}

Whether the "dorinant foreign affairs" power precludes state action that indirectly affects foreign affairs lias not been unequivocally decided. Nor has the Court clearly articulated standards to ineasure whether state action directly or indirectly affects foreign affairs. In Zschernig v. Miller, ${ }^{70}$ the Court invalidated an Oregon statute that provided for escheat of a nonresident alien's property claims uuless United States citizens enjoyed reciprocal rights to take property under the laws of the alien's loone country. ${ }^{71}$ The Court found the statute preempted because it effectively scrutinized and criticized foreign governments "established on a inore authoritarian basis than our own."72 Such criticisin constituted an impermissible intrusion by Oregon into "foreign affairs and international relations-inatters which the Constitution entrusts solely to the Federal Government."73 The Court did not rely on any treaties or other federal enactinents. ${ }^{74}$

As part of its holding, the Court did not adequately reconcile Clark v. Allen, ${ }^{75}$ a case in which the Court had upheld a substantially identical Califormia statute that conditioned the right of a nonresident alien to acquire property on reciprocal rights of American citizens in the country froin which the alien came. ${ }^{76}$ The Court in Clark rejected the argument that such a statute was an extension of state power into the field of foreigu affairs. Reasoning that no treaty governed the rights of succession to personal property, the Court found that California had not "entered the forbidden domam of negotiating witl a foreigu country."77 Thus, the

69. See Silkwood v. Kerr-McGee, 464 U.S. 238, 256 (1984) ("[i]t may be that the award of damages based on the state law of negligence is . . . regulatory").

70. 389 U.S. 429 (1968).

71. Id. at 430 .

72. Id. at 440 .

73. Id. at 436 .

74. Id. at 441. As Justice Harlan stated, the Court did not "paus[e] to consider whether the 1923 Treaty of Friendship, Commerce and Consular Riglits with Germany itself vitiates the application of the state statute." Id. at 443 (Harlan, J., concurring) (footnote omitted).

75. 331 U.S. 503 (1947).

76. Id. at $506 \mathrm{n} .1$.

77. Id. at 517 . 
objection that the statute impermissibly intruded on foreign affairs was "farfetched."78 Although what California did would "have soine incidental or indirect effect in foreign countries," the Court noted "that is true of inany state laws which none would claim cross the forbidden line."79

Reconciling Clark with Zschernig is difficult. The Court upheld the state statute at issue in Clark because the Court found that it ouly had an "incidental or indirect" effect on foreign relations, ${ }^{80}$ whereas the Court invalidated a similar statute in Zschernig because the Court concluded that it had a "direct impact upon foreign relations."81 One way to harmonize the cases is to conclude that where a state statute directly affects foreign relations, the Court will imply a federal interest directly under the Constitution and will invalidate the state legislation. In contrast, where a state statute ouly indirectly affects foreign relations, the Court will require a conflict with an articulated (by treaty, statute, or similar means) federal interest before it will preempt. Given the substantial similarity between the statutes in Clark and Zschernig, however, the Court's distinction between direct and indirect impacts on foreign relations reinains unclear.

Unfortunately, other cases are equally confusing. In Hines v. Davidowitz, ${ }^{82}$ the Court struck down a Peimsylvania act that required every alien eighteen years of age or older to register yearly or face criminal sanctions. ${ }^{83}$ Justice Black, writing for the majority, discussed the federal interest in regulating foreign relations. The federal government, he wrote,

is entrusted with full and exclusive responsibility for the conduct of affairs with foreign sovereignties. "For local interests the several States of the Union exist, but for national purposes, enibracing our relations with foreign nations, we are but one people, one nation, one power." Our systen of government is such that the interest of the cities, counties and states, no less than the interest of the people of the whole nation, imperatively requires that federal power in the field affecting foreign relations be left entirely free froun local interference. ${ }^{84}$

The Court also cited The Federalist as authority for the argument that the federal goverimient has exclusive regulatory power over foreign affairs. ${ }^{85}$ The thrust of Justice Black's language suggested that the Con-

\footnotetext{
78. Id.

79. Id.

80. Zschernig v. Miller, 389 U.S. 429, 434 (1968).

81. Id. at 441 .

82. 312 U.S. 52 (1941).

83. Id. at 59,74 .

84. Id. at 63 (quoting Chinese Exclusion Case, 130 U.S. 581, 606 (1889)).

85. Id. at $62 \&$ n.9 (citing The Federalist No. 23 (J. Jay), No. 4 (J. Jay), No. 5 (J. Jay), No. 42 (J. Madison), and No. 80 (A. Hamilton)).
} 
stitution itself, independent of any statute, limits state power over foreign affairs. However, Justice Black expressly declined to address whether federal power, exercised or unexercised, in the field of immigration would be exclusive. ${ }^{86}$ Instead, the opinion examined congressional enactınents to determine "whether Congress has, by its action, foreclosed enforcement" of the state's alien registration law. ${ }^{87}$ The Court then used the Federal Alien Registration Act of 1940, and not the Constitution, to preempt the state statute. ${ }^{88}$

In De Canas v. Bica, ${ }^{89}$ the Court seemed to go further toward denying the existence of a "dormant foreign affairs" power that invalidates state legislation indirectly affecting foreign affairs. The Court upheld a Califorma statute that prohibited state einployers froin employing undocumented aliens if such employment would adversely affect the resident work force. ${ }^{90}$ The Court wrote that while the power to regnlate immigration was exclusively a federal power, "the Court has never held that every state enactınent which in any way deals with aliens is a regnlation of immigration and thus per se pre-empted by this constitutional power, whether latent or exercised."91 The Court reasoned:

[T] here would have been no need, in cases such as . . Hines v. Davidowitz ... even to discuss the relevant congressional enactments in finding pre-emption of state regulation if all state regulation of aliens was ipso facto regulation of immigration, for the existence vel non of federal regulation is wholly irrelevant if the Coustitution of its own force requires pre-emption of such state regulation. ${ }^{92}$

In effect, the Court held that no dormant power in the Constitution prohibits states from enacting a law that "has some purely speculative and indirect inupact on immigration." 93

The Supreme Judicial Court of Massachusetts has adopted this approach. In Arthur D. Little, Inc. v. Commissioner of Health and Hospitals of Cambridge, ${ }^{94}$ the court upheld a Cambridge regulation that prohibited the testing, storage, transportation, and disposal within city limits of chemical warfare agents. ${ }^{95}$ The court exphicitly rejected the contention that the regnlation was preempted by "the Constitution's grant of war and defense powers to the Federal government." Although the

\footnotetext{
86. See id. at 61-62.

87. Id. at 62.

88. Id. at $72-74$.

89. 424 U.S. 351 (1976).

90. Id. at 355 .

91. Id.

92. Id. (citations omitted).

93. Id.

94. 395 Mass. 535, 481 N.E.2d 441 (1985).

95. Id. at 537, 547, 481 N.E.2d at $444,455$.

96. Id. at 546,481 N.E.2d at 449.
} 
court recognized that national defense is a federal concern, it stated that "not every regulation which has some incidental effect on a defense program is invalid under the supremacy clause."97 Because the record suggested that the regulation would have nothing "more than a 'speculative and indirect impact' ... on the national defense,"98 and because it did not favor precmption, ${ }^{99}$ the court upheld the regulation.

\section{Nuclear Free Zones and the "Dormant Foreign Affairs" Power}

Although the Court has not fully articulated a "dormant foreign affairs" doctrine, it has suggested the outline of such a doctrine, which can be apphied to nuclear free zones. On the one hand, the Court strongly disapproves of state action that directly affects national military affairs. ${ }^{100}$ While the Court has not defined what constitutes a direct impact on foreign affairs, it has held that state actions attempting to regulate troop deployment are direct. ${ }^{101}$ Tarble's Case and Perpich both involved attempts to control the actual movement of troops, and in both cases the Court found that the Constitution precluded the state action. ${ }^{102}$ Consequently, it is likely that nuclear frec zones that directly regulate troops or the deployment of weapons would be held unconstitutional.

On the other hand, nuclear free zones that regulate ouly the production of nuclear weapons and their component parts may survive constitutional challenges. Under Boyle, ${ }^{103}$ state regulation that affects the federal government's ability to procure weapons, but does not directly interfere with the government's discretion to design and procure specific types of weapons, may be permissible if the regulation furthers a legitimate state interest. ${ }^{104}$ Since nuclear free zones prohibiting the production of nuclear weapons and parts on private property affect only the federal government's power to procure weapons from certain manufacturers in discrete areas and do not directly interfere with the federal government's

97. Id.

98. Id. at 547, 481 N.E.2d at 449 (quoting De Canas v. Bica, 424 U.S. 351, 355 (1976)).

99. Id. at $545-46,481$ N.E.2d at 448 .

100. See supra discussion at Part II(A).

101. See, e.g., Perpich v. Department of Defense, 110 S. Ct. 2418 (1990); Tarble's Case, 80 U.S. (13 Wall.) 397 (1871). For a discussion of Perpich and Tarble's Case, see supra text accompanying notes $34-53$.

102. See also Fossella v. Dinkins, 66 N.Y.2d 162, 485 N.E.2d 1017, 495 N.Y.S.2d 352 (1985). In Fossella, the New York Appellate Division and the New York Supreme Court found that the foreign affairs clauses precluded an attempt to regulate the deployinent of nuclear vessels in New York harbors. See supra text accompanying notes 58-64.

103. 487 U.S. 500 (1988); see supra text accompanying notes 65-69.

104. For a discussion of the legitimate state economic interests that could support the implementation of a nuclear free zone prohibiting the production of nuclear weapons and parts, see infra Part IV. 
power to design and procure weapons, they may withstand constitutional challenge.

Further, like Cambridge's antichemical regulations, nuclear free zones prohibiting the construction of nuclear weapons and weapons parts would have ouly an indirect impact on the national defense. First, it is very unlikely that enough communities would adopt such regulations so as to significantly impair the construction of nuclear weapons. ${ }^{105} \mathrm{Sec}-$ ond, even if every community in the United States restricted production of nuclear weapons, the federal government has both the statutory power and the physical ability to nianufacture nuclear weapons in its own facilities. ${ }^{106}$ Third, should a nuclear free zone epidemic occur, Congress could pass legislation to prohibit such ordinances.

Finally, there are strong federalism concerns that militate against adopting a broad interpretation of the "dormant foreign affairs" power. An overbroad "dormant foreign affairs" power would permit the federal government to displace otherwise proper state legislation. Many laws enacted under a state's police powers, from probate to labor, ${ }^{107}$ will in soine way affect foreign affairs. In order to displace such laws, the Court should require that the federal government clearly articulate its preemptive intent, either by statute or through the Constitution. The abrogation of state sovereignty requires proper representation by the states. ${ }^{108}$ One commentator argnes that this approach promotes "the spirit of Garcia [v. San Antonio Metropolitan Transit Authority] by requiring that decisions restrictimg state sovereignty be inade in a dehiberate nuanner by Congress." 109 These policy concerns enhance the possibility of the constitutionality of limited nuclear free zone ordinances.

III

Federal Statutory Preemption: The Atomic ENERGY ACT ${ }^{10}$

Even if nuclear free zones prohibiting the inanufacture of nuclear

105. See infra text accompanying notes $245-46$.

106. See infra text accompanying notes $247-48$.

107. See De Canas v. Bica, 424 U.S. 351 (1976) (involving labor law); Zschernig v. Miller, 389 U.S. 424 (1968) (involving probate law).

108. Garcia v. San Antonio Metro. Transit Auth., 469 U.S. 528, $550-54$ (1985).

109. L. Tribe, AMerican ConstTtutional LAw 480 (2d ed. 1988) (suggesting federal government should be required to state clearly that it is using its power to restrict state sovereignty in the area of the dormant commerce clause). For a discussion of state sovereignty in the context of the dormant commerce clause, see Eule, Laying the Dormant Commerce Clause to Rest, 91 Yale L.J. 425 (1982) (arguing for diminished role for dormant commerce clause); Redish \& Nugent, The Dormant Commerce Clause and the Constitutional Balance of Federalism, 1987 DukE L.J. 569 (concluding federal judiciary undermines governmental structure established by the Constitution when it uses dormant foreign affairs clause to invalidate state regulations).

110. 42 U.S.C. $\$ \S 2011-2296$ (1988). 
weapons and parts withstand a constitutional preclusion challenge, they may still be preempted by the AEA, the primary federal statute governing nuclear power and weapons. Any valid exercise of Congress' legislative power is the supreme law of the land. ${ }^{111}$ State or local legislation that obstructs the "accomplishment and execution of the full purposes and objectives [of an act] of Congress" is preempted by the federal act. ${ }^{112}$ Specifically, federal law preempts state legislation in two ways: first, congressional design to "preempt [or occupy] the field" renders state legislation in the same area unconstitutional; ${ }^{113}$ second, conflict between federal and state statutes invalidates the state action. ${ }^{114}$

\section{A. Federal Occupation of the Field}

When Congress clearly manifests its intent to occupy a field of regulation, federal action supersedes state action in that field whether or not the state action actually impedes the operation of federal law. ${ }^{115}$ However, Congress rarely states the purpose of its legislation clearly. As a result, courts must often divine Congress' intent. ${ }^{116}$ To this end, the Supreme Court has developed several interpretive tools.

In some cases, the Court searches for "objective" factors that demonstrate a "clear and manifest purpose of Congress" to preeinpt a field. ${ }^{117}$ In Rice v. Santa Fe Elevator Co., ${ }^{118}$ Justicc Douglas articulated some objective factors:

Such a purpose [to supersede historic state police powers] may be evidenced in several ways. The scheme of federal regulation may be so pervasive as to make reasonable the inference that Congress left no room for the States to supplement it. Or the Act of Congress may touch a field in which the federal interest is so dominant that the federal system will be assumed to preclude enforcement of state laws on the same subject. Likewise, the object sought to be obtained by the federal law and the

111. U.S. ConsT. art. VI, § 2.

112. Hines v. Davidowitz, 312 U.S. 52, $66-67$ (1941).

113. See Florida Lime \& Avocado Growers, Inc. v. Paul, 373 U.S. 132, $141-52$ (1963) (upholding constitutionality of California statute because it did not directly conflict with federal regulation and because there was no evidence of congressional intent to preempt the field).

114. Id. For more extensive discussions of preemption doctrine, see Hirsch, Toward a New View of Federal Preemption, 1972 U. ILI. L.F. 515 (focusing on thrce aspects of preemption: diversity of problems, applicable judicial standards, and Court's self-defined role in decisionmaking); Note, The Preemption Dactrine: Shifting Perspectives on Federalism and the Burger Court, 75 CoLUM. L. REV. 623-24 (1975) (examining Burger Court's preeinption decisions, which favored concurrent state and federal regulation); Comment, supra note 23 (defending Supreme Court's preemption rulings against judicial and scholarly criticism).

115. Florida Lime \& Avocado Growers, 373 U.S. at 146.

116. Wiggins, Federalism Balancing and the Burger Court: California's Nuclear Law as a Preemption Case Study, 13 U.C. DAVIS L. REv. 3 , 23 (1979).

117. Rice v. Santa Fe Elevator Corp., 331 U.S. 218, 230 (1947).

118. 331 U.S. 218 (1947). 
character of obligations imposed by it may reveal the same purpose. ${ }^{119}$ Although the Court has rarely used these factors as conditions precedent to finding preemption, many preemption decisions used some combimation of these terms to frame the issues. ${ }^{120}$ Some commentators have criticized this aspect of preemption doctrine. Although the Court uses "objective standards" to determine Congress' intent, some authors claim these standards are ambiguous and allow the Court to impose its own subjective views. ${ }^{121}$

In other cases, the Court does not look at objective factors but rehes instead on "subjective" factors. This approach requires a clear and express manifestation of Congress' intent to preempt. The Court has articulated the subjective intent test in a variety of ways. In Mintz $v$. Baldwin, ${ }^{122}$ the Court held that absent an "actual conflict" between federal and state law, preenption could occur only if congressional imtent to occupy the field was "definitely and clearly" shown. ${ }^{123}$ Although the Court has not apphed the test consistently, later cases have emphasized this approach. In New York State Department of Social Services v. Dublino, ${ }^{124}$ for example, the Court held that

[i]f Congress is authorized to act im a field, it should manifest its intention clearly. It will not be presumed that a federal statute was intended to supersede the exercise of the power of the state unless there is a clear manifestation of intention to do so. The exercise of federal supreinacy is not hightly to be presumed. ${ }^{125}$

By limiting federal interests to those clearly expressed by Congress, ${ }^{126}$ the subjective intent test is considerably more deferential to

119. Id. at 230 (citations omitted).

120. See, e.g., City of Burbank v. Lockheed Air Terminal, 411 U.S. 624, 633-34 (1973) (pervasiveness of federal scheme indicated congressional imtent to occupy field); Hines $v$. Davidowitz, 312 U.S. 52, 69-74 (1941) (dominance of federal interest in area of immigration indicated congressional intent to occupy field). It is often difficult to distinguish the Court's discussion of dominant federal interest as an indicator of congressional intent to preempt and dominant federal interests as constitutionally preeluding state action. This may be a result of the two tests' functional similarities. See, eg., Comment, supra note 33, at 972 ("what the Court has portrayed as constitutional preelnsion arguments may be better understood in terms of statutory preemption analysis").

121. See, e.g., Hirsch, supra note 114, at 516-19, 525 (noting conclusory character of Court's standards and detailing widely varying apphications to various fields of state regulation). But see Wiggins, supra note 116, at 23-24 ("personalized view of the Justice's role may be both necessary and desirable").

122. 289 U.S. 346 (1933).

123. Id. at 350 . The Court has articulated other phrasings of the test. See Maurer v. Hamilton, 309 U.S. 598, 614 (1940) (congressional intent "clearly indicated"); H.P. Welsh Co. v. New Hampshire, 306 U.S. 79, 85 (1939) (congressional intent "definitely expressed").

124. 413 U.S. 405 (1973).

125. Id. at 413.

126. See Note, supra note 114 , at 626-30, 639-53 (arguing strict intent standard allows states to legislate in areas of state interest without diminishing the primciple of federal supremacy). 
state interests than the objective factors approach. Thus, unlike the objective factors test, the subjective intent test prohibits the courts from "filling in the gaps" with presumed interests where Congress has failed to clearly state its intentions.

\section{B. Conflict with Federal Action}

The second category of preemption involves state legislation that conflicts with a federal act. The test requires the Court to interpret the state and federal statutes at issue and determine whether the statutes conflict. ${ }^{127}$ A paradigm case of conflict preemption occurs when a state act requires behavior a federal act prohibits. ${ }^{128}$ Such cases, however, are rare and "[a]s the scope of state interference with a federal legislative scheme diminishes ... the presencc of conflict becomes progressively more subtle." 129 Consequently, whether a state statute "conflicts" with a federal statute often depends upon what degree of inconsistency between the statutes the Court accepts. ${ }^{130}$ As with occupational preemption, conflict preeinption grants considerable deferencc to the states. As one commentator has concluded, "where a conflict is unripe or peripheral to the purpose of the federal statute, state legislation will be allowed to stand."131

\section{Two Preemption Cases in the Area of Nuclear Power}

Two recent cases in the context of nuclear power illustrated the Court's trend toward favoring state interests when deciding whether state law is preempted by a federal statute. If this trend were applied to nuclear free zones, the Court may find that such ordinances are not statutorily preempted. In Paciflc Gas \& Electric Co. v. State Energy Resources Conservation \& Development Commission ${ }^{132}$ and Silkwood $v$. Kerr-McGee Corp., ${ }^{133}$ the Court considered the preemptive effect of the $\mathrm{AEA}^{134}$ in the area of nuclear power. These cases are important for

127. Perez v. Campbell, 402 U.S. 637, 644 (1971).

128. See Florida Lime \& Avocado Growers, Inc. v. Paul, 373 U.S. 132, 142-43 (1963) ("A holding of federal exclusion of state law is inescapable and requires no inquiry into congressional design where comphiance with both federal and state regulations is a physical impossibility.").

129. Note, supra note 114 , at 626.

130. See, e.g., Goldstein v. California, 412 U.S. 546, 554 (1973) ("We must also be careful to distinguish those situations in which the concurrent exercise of a power by the Federal Government and the States or by the States alone may possibly lead to conflicts and those situations where conflicts will necessarily arise.") (enuphasis in original); Garner v. Teamsters Union, 346 U.S. 485, 490-91, 501 (1953) (possibility of incoinpatible adjudications resulting from inultiple tribunals and different rules of substantive law preempted state adjudication of labor case).

131. Note, supra note 114 , at 653 .

132. 461 U.S. 190 (1983).

133. 464 U.S. 238 (1984).

134. 42 U.S.C. $\$ \S 2011-2296$ (1988). 
determining the constitutionality of nuclear free zones because the AEA also governs the development of nuclear weapons. As discussed below, the AEA treats the hicensing of nuclear weapons and nuclear power similarly. As a result, this Comment argues that Pacific Gas \& Electric and Silkwood enhance the survivability of nuclear free zones.

\section{Pacific Gas \& Electric}

In 1974, the California state legislature passed the Warren-Alquist State Energy Resources Conservation and Development Act ("Act"). ${ }^{135}$ The Act required a utility seeking to build an electric power plant, mcludimg a nuclear power plant, to apply for certification from the California State Energy Resources Conservation and Development Commission. ${ }^{136}$ In 1976, the state legislature amended the Act, imposing a moratorium on the construction of new nuclear plants until the Nuclear Regulatory Commission ("NRC") developed an effective method for the permanent disposal of nuclear wastes, ${ }^{137}$ and barring the state energy commission from certifying new nuclear plant construction in the absence of adequate waste storage facilities. ${ }^{138}$

In response to the 1976 amendment, the Pacific Gas \& Electric Company ("PG\&E") filed suit claiming that the AEA preeinpted the inoratorium. ${ }^{139}$ The district court found that the AEA established a federal scheine of nuclear regulation and thus preempted the state moratorium. ${ }^{140}$

Reversing the district court's ruling, the Ninth Circuit Court of Appeals held that sections 271 and 274 of the AEA indicated that Congress intended to preempt state regulation of nuclear facilities only in matters concerning radiation safety. ${ }^{141}$ The court found that because the legislative history of the Act indicated that it had an economic purpose, the Act did not infringe upon the occupied field of radiation safety. ${ }^{142}$ The court also concluded that the Act did not conflict with Congress'

135. Warren-Alquist State Energy Resources Conservation and Development Act, ch. 276, $§ 2$, 1974 Cal. STAt. 500 (codified as amended at CAL. Pub. REs. CoDe $\S \S 25000-25986$ (West $1986 \&$ Supp. 1991)).

136. Id. at 503, 526 (codified as amended at CAL. PuB. REs. CoDE $\$ \S 25519,25110,25120$ (West 1986 \& Supp. 1991)).

137. Id. ch. 196, § 1(a), 1976 CAL. STAT. 378.

138. Id. ch. 194, § 1, 1976 CAL. STAT. 374.

139. Pacific Gas \& Elec. Co. v. State Energy Resources Conservation \& Dev. Comm'n, 489 F. Supp. 699 (E.D. Cal. 1980), rev'd sub nom. Pacific Legal Found. v. State Energy Resources Conservation \& Dev. Comm'n, 659 F.2d 903 (9th Cir. 1981), aff'd sub nom. Pacific Gas \& Elec. Co.

v. State Energy Resources \& Dev. Comm'n, 461 U.S. 190 (1983).

140. Id. at 703.

141. Pacific Legal Found. v. State Energy Resources Conservation \& Dev. Comm'n, 659 F.2d 903, 926-27 (9th Cir. 1981), aff'd sub nom. Pacific Gas \& Elec. Co. v. State Energy Resources Conservation \& Dev. Comm'n, 461 U.S. 190 (1983).

142. Id. at 923-25. 
objective to develop nuclear power. The court found that while Congress intended to promote the private development of nuclear power, it did not intend to promote the industry "at all costs." 143

Affirming the Ninth Circuit's ruling, the United States Supreme Court agreed with the Ninth Circuit's conclusion that Congress did not intend to occupy the entire field of nuclear power regulation. ${ }^{144}$ The Court recognized that even though the AEA granted Congress exclusive power to hicense all nuclear technology, it did not provide that Congress could decide whether and where nuclear plants should be built. ${ }^{145}$ Instead, under section 271 of the AEA, such economic decisions were left to the states. ${ }^{146}$

In its preenption analysis, the Court drew a formal distinction between safety and economics. Interpreting the legislative history behind the Act, the Court found that California appeared to be motivated by economic concerns that did not encroach upon federal authority. ${ }^{147}$ Although the Court recognized that safety and economic concerns were closely intertwined in the nuclear waste issue, it concluded that the lack of safe, long-term storage space could lead to reactor shutdowns, "renderimg nuclear energy an unpredictable and uneconomical adventure."148 Because legislative motivation is usually ambiguous and because California could have refused on economic grounds to issue any utility licenses, the Court accepted the moratorium's avowed cconomic purposes and found that the statute lay outside the occupied field of nuclear safety regulation. ${ }^{149}$

The Court then addressed PG\&E's argument that the moratorium conflicted with Congress' judgment that it was "permissible to continue to hicense reactors, notwithstanding uncertainty surrounding the waste disposal problem."150 The Court held that the NRC's regulations were

143. Id. at 926.

144. Pacific Gas \& Elec. Co. v. State Energy Resources Conservation \& Dev. Comm'n, 461 U.S. $190,222-23$ (1983).

145. Id. at 207.

146. Id. at 207-08. Section 271 of the AEA provides that "[n]othing in this chapter shall be construed to affect the authority or regulations of any Federal, State or local agency with respect to the generation, sale, or transmission of electric power produced through the use of nuclear facilities licensed by the Commission ... ." Atomic Energy Act of 1954, 42 U.S.C. $\$ 2018$ (1988).

147. Pacific Gas \& Electric, 461 U.S. at 213-16. The Court relied primarily on a report by the California State Assembly Committee on Resources, Land Use and Energy. In the report, the Committee explained that "the waste disposal problem was "largely economic or the result of poor planning, not safety related." Id. at 213 (emphasis in original) (quoting California State ASSEMBly COMMITTEe ON RESOURCES, LAND USE \& ENERGY, REASSESSMENT OF NUCLEAR Energy in California: A Policy Analysis of Proposition 15 and Its Alternatives 18 (1976)).

148. Id. at 196-97.

149. Id. at 216 .

150. Id. at 217 . 
motivated by safety and not economic concerns. ${ }^{151}$ Consequently, compliance with both the federal policy and the California moratorium was possible. $^{152}$

Lastly, although the Court found that a primary purpose of the AEA was to develop the commercial use of nuclear power, Congress did not support the development of nuclear power "at all costs." 153 States lad "sufficient authority ... to allow the development of nuclear power to be slowed or even stopped for economic reasons." 154 Thus, the economically based moratorium was not preempted.

\section{Silkwood v. Kerr-McGee Corp.}

In Silkwood v. Kerr-McGee Corp., ${ }^{155}$ the Supreme Court addressed whether the regulatory scheme of the AEA preempted state common law tort remedies. Karen Silkwood, a laboratory worker and umon representative at Kerr-McGee's plutomum fuel pim manufacturing plant, brouglit suit under state law for personal imjuries and property damage allegedly resulting from plutomum contamination. ${ }^{156}$ The district court upheld a verdict returned by the jury for $\$ 5,000$ in property damages, $\$ 500,000 \mathrm{in}$ personal imjury damages, and $\$ 10,000,000$ in punitive damages. ${ }^{157}$

The Umited States Court of Appeals for the Tentli Circuit affirmed the award of property damages but reversed the awards for personal imjury and punitive damages. ${ }^{158}$ The Tenth Circuit found that while the Price-Anderson Act, ${ }^{159}$ a federal statute that limits a utility's liability for mjuries caused by a nuclear aceident, did not preempt awards under state law for property damage caused by radiation, the AEA entirely preempted punitive damages. ${ }^{160}$ The court found that pumitive damages were essentially a forn of regulation and that the AEA preempted state regulation of radiation liazards. ${ }^{161}$

Reversing the Tenth Circuit's decision, the Umited States Supreme

151. Id. at 218 .

152. Id. at 219.

153. Pacific Gas \& Electric, 461 U.S. at 221-22 (quoting Pacific Legal Found. v. State Energy Resources Conservation \& Dev. Comm'n, 659 F.2d 903, 926 (9th Cir. 1981)).

154. Id. at 223.

155. 464 U.S. 238 (1984).

156. Silkwood v. Kerr-McGee Corp., 485 F. Supp. 566 (W.D. Okla. 1979), aff'd in part, rev'd in part, 667 F.2d 908 (10th Cir. 1981), rev'd, 464 U.S. 238 (1984).

157. Id. at $570,589-91$.

158. Silkwood v. Kerr-McGee Corp., 667 F.2d 908, 923 (10th Cir. 1981), rev'd, 464 U.S. 238 (1984).

159. Pub. L. No. 85-256, 71 Stat. 576 (1957) (codified as amended at 42 U.S.C. $\$ \S 2012,2014$, $2039,2073,2210,2232,2239$ (1988)).

160. Silkwood, 667 F.2d at 923. The Court also reversed the district court's award of personal injury damages, holding that such an award was barred by the Oklahoina workers' compensation statute. Id. at 920 .

161. Id. at $922-23$ (citing Northern States Power Co. v. Minnesota, 447 F.2d 1143 (8th Cir. 
Court addressed only the issue of punitive damages. ${ }^{162}$ Kerr-McGee argued that the damages award should be preempted because the award was a form of regulation, and only the federal government can regulate nuclear safety issues under the AEA. ${ }^{163}$ The Court, however, disagreed. Examining the legislative history of the Price-Anderson Act and the AEA, the Court concluded that Congress had intended to leave traditional state common-law reinedies for injuries caused by nuclear facilities intact, except where exphicitly displaced by federal law. ${ }^{164}$

The Court then noted the "tension between the conclusion that safety regulation is the exclusive concern of the federal law and the conclusion that a State may nevertheless award damages based on its own law of hability." 165 It concluded, however, that since Congress aceepted this tension when it enacted the AEA and the Price-Anderson Act, it was bound to respect that decision. ${ }^{166}$

The Court then proposed a standard for determining whether state interests in awarding damages for radiation injuries should be preempted:

[P]re-emption should not be judged on the basis that the Federal Government has so completely occupied the field of safety that state remedies are foreclosed but on whether there is an irreconcilable conflict between the federal and state standards or whether the imposition of a state standard in a damages action would frustrate the objectives of the federal law. ${ }^{167}$

The Court found that Silkwood's punitive damages award was not preeinpted because a nuclear power plant could pay both federal fines and state law punitive damages for the same incident without frustrating the purpose behind the federal reinedy. ${ }^{168}$

Finally, the Court rejected Kerr-McGec's contention that an award of punitive damages conflicted with Congress' intent to encourage the development of atomic energy. ${ }^{169}$ As in Pacific Gas \& Electric, Congress'

1971), aff'd mem. 405 U.S. 1035 (1972) (holding AEA preempts state regulation of radiation hazards)).

162. Silkwood v. Kerr-McGee Corp., 464 U.S. 238 (1984).

163. Id. at 249-51.

164. Id. at 249-56. Specifically, the Court examined a 1966 amendinent to the Price-Anderson Act that allowed the Atomic Energy Commission to require licensees of nuclear technology to waive certain state law defenses in lawsuits resulting from an "extraordinary nuclear occurrence." Id. at 253-54 (citing Price-Anderson Act, Pub. L. No. 89-645, 80 Stat. 891 (1966) (codified as amended at 42 U.S.C. $\$ 2210(n)(1)(1982))$ ). From this waiver requirement, the Court reasoned that Congress assumed state common law remedies, whicl include punitive damages, would remain intact, despite exclusive federal regulation of safety issues. $I d$. at 252-56.

165. Id. at 256.

166. Id.

167. Id.

168. Id. at 257.

169. Id. 
goal of promoting nuclear power was not to be accoinplished "at all costs." 170

\section{The Preemption Standards Articulated in Pacific Gas \& Electric and Silkwood and the Trend Toward Favoring State Interests}

Although the Court lias not applied any one preenption doctrine consistently, several commentators liave noted that recent cases tend to favor state interests. ${ }^{171}$ Indeed, a number of cases seem to disapprove of the use of the objeetive factors articulated in Rice v. Santa Fe Railroad ${ }^{172}$ to determine congressional intent. ${ }^{173}$ For example, in New York State Department of Social Services v. Dublino, ${ }^{174}$ a case addressing whetler the Federal Aid for Dependent Children statute preeinpted a New York welfare statute, the Court refused to find congressional intent to preempt state action witlout "direct and unambiguous [preemptive] language" in the federal act or its legislative history. ${ }^{175}$ Justice Powell wrote that the Court rejeeted "tlie contention that pre-einption is to be inferred inerely from the comprehensive cliaracter of the federal work incentive provisions .... Given the coinplexity of the matter addressed by Congress in [the Act], a detailed statutory scheme was both likely and appropriate, completely apart from any questions of pre-emptive intent."176

Botli Pacific Gas \& Electric and Silkwood continued this trend and left to Congress the task of correcting any logical infirmities that the Court's reasoning produced. In neitler case did the Court apply the objective pervasiveness and dominant federal interest standards articulated in Rice when determining whether the AEA oceupied the field. ${ }^{177}$ Basing its holdings almost entirely on legislative history, the Court relied instead on the subjective interest test. The Court in botll cases refused to supply preeinptive intent even though a broad reading of congressional purposes would have necessitated suclı a finding. In order to preeinpt state regulatory actions, the Court in Pacific Gas \& Electric deinanded

170. Id. (quoting Pacific Gas \& Elec. Co. v. State Energy Resources Conservation \& Dev. Comm'n, 461 U.S. 190, 222 (1983)).

171. See Wiggins, supra note 116 , at 31-56; Note, supra note 114, at 639-54.

172. 331 U.S. 218 (1947).

173. See supra text accompanying notes 118-19.

174. 413 U.S. 405 (1973).

175. Id. at 414 (citations omitted).

176. Id. at 415. See also De Canas v. Bica, 424 U.S. 351, 359-60 (1976) (comprehensiveness expected of federal immigration statute and thus irrelevant to determination of intent to preempt). For a discussion of the weakening of the dominant federal interest test, see Wiggins, supra note 116, at 33-39; see also Boyle v. Umited Technologies Corp., 487 U.S. 500, 508-10 (1988) (finding state tort law affecting military contractors preempted only where certain conditions met); De Canas, 424 U.S. at 355-56 (1976) (finding state labor act regulating aliens permissible despite dominant federal interest in immigration).

177. See supra text accompanying notes 118-19. 
that Congress "expressly require the States to construct . . . nuclear power plants or prohibit the States from [declining further construction]."178

Although the nuclear industry is among the nation's most heavily regulated fields, the pervasiveness of regulation did not seem to have been an issue. In Pacific Gas \& Electric, the Court concluded:

Even a brief perusal of the Atomic Energy Act reveals that, despite its comprehensiveness, it does not at any poimt expressly require the States to construct or authorize nuclear powerplants or prohibit the States from decidimg, as an absolute or conditional matter, not to permit the construction of any further reactors. ${ }^{179}$

Thus, $\mathrm{m}$ the field of nuclear power, pervasiveness was insufficient to show a congressional intent to preeinpt state law.

Further, the Court did not disturb the trend toward allowing tension to exist between state interests and dominant federal interests. Although the Court found that the federal authority over nuclear safety was exclusive and preempted state regulation, ${ }^{180}$ it did so not by reciting the need for national uniformity, but rather by its interpretation of the AEA. ${ }^{181}$ And it did not extend that authority to closely related fields to avoid possible tension. ${ }^{182}$ In Pacific Gas \& Electric, the economics of nuclear power plants were separated from safety issues, ${ }^{183}$ and in Silkwood, tort damages for violations of safety standards were separated from safety regulations, ${ }^{184}$ even though these distinctions are soinewhat formalistic. ${ }^{185}$

178. Pacific Gas \& Elec. Co. v. State Energy Resources Conservation \& Dev. Comm'n, 461 U.S. 190,205 (1983) (emphasis added).

179. Pacific Gas \& Electric, 461 U.S. at 205 (emphasis added).

180. Id. at 212; Silkwood v. Kerr-McGee Corp., 464 U.S. 238, 249 (1984) (citing Pacific Gas \& Electric, 461 U.S. at 212).

181. Pacific Gas \& Electric, 461 U.S. at 212-13; see supra text accompanying notes 144-54.

182. In Silkwood, the Court recognized and accepted the tension in its holding. See supre text accompanying notes 165-66. Although Pacific Gas \& Electric did not exphicitly acknowledge doctrinal tension, the exclusive federal interest in nuclear safety regulations is difficult to sever from California's economic decision not to build reactors. As one commentator has argued, "[i]rrespective of the stated purposes of California's moratorium on nuclear plant construction, one consequence that the law will have is the reduction in radiation hazards, thereby intruding on the assertedly occupied field." Note, Federal Supremacy Versus Legitimate State Interests in Nuclear Regulation: Pacific Gas \& Electric and Silkwood, 33 CATH. U.L. Rev. 899, 933 (1984).

183. See supra text accompanying notes 147-49.

184. See supra text accompanying notes 163-66.

185. The Pacific Gas \& Electric Court's cursory acceptance of California's stated purpose is an example of this formalism. While legislative motivation may, as the Court asserted, be ambiguous, ample evidence indicated that California was inotivated by safety concerns. 461 U.S. at 216. The report by the California State Assembly Committee on Resources, Land Use \& Energy, upon which the Court heavily relied to find an economic purpose, also extensively discussed nuclear safety issues. See California State assembly Committee on Resources, land Use \& Energy, Reassessment of Nuclear Energy in California: A Policy Analysis of Proposition 15 AND ITS ALTERNATIVES 31-58 (1976). Because a state can simply "halt the construction of new 
Even read narrowly, Pacific Gas \& Electric and Silkwood have an impact on the "occupation of the field" preemption analysis applied to nuclear free zones. At the very least, they indicate that the Court will tend to uphold state regulations based on traditional police powers, sucl as economic regulations. They also indicate that a challenger will have to point to express preeinptive language in order to prove that Congress intended to occupy a field. Therefore, the subjective intent approach to occupational preemption applied in Pacific Gas \& Electric and Silkwood, and not the stricter objective factors approach, sliould be apphed to the preemption analysis of nuclear free zones under the AEA.

As with occupational preemption, conflict preemption grants considerable deference to the states. For a conflict between federal and state statutes to justify judicial action, "rather than cooperative federal-state resolution, [tle conflict] slould be of substance and not merely trivial or insubstantial." 186 This indicates that conflict preemption requires more than the possibility of conflict or minimal conflict. As one commentator has concluded, "where a conflict is unripe or peripheral to the purpose of the federal statute, state legislation will be allowed to stand."187

Pacific Gas \& Electric and Silkwood continued the trend toward granting considerable deference to states. Botli applied a conflict standard that deferred to state interests and tolerated substantial tension between federal and state regulations. The Court in Pacific Gas \& Electric, concluding that states were frce to slow or even stop the development of nuclear power "for economic reasons," reasoned that "it is for Congress to rethink the division of regulatory authority in hilit of its possible exercise by the States to undercut a federal objective." 188 Similarly, rather than imply a conflict, the Court in Silkwood required an "irreconcilable conflict between the federal and state standards." 189

The Court's tendency to give states considerable latitudc to legislate

nuclear plants by refusing on economic grounds to issue certificates of public convenience in individual proceedings," the Court did not want to become "embroiled in attempting to ascertain California's true motive." Pacific Gas \& Electric, 461 U.S. at 216.

186. New York State Dep't of Social Servs. v. Dublino, 413 U.S. 405, 423 n.29 (1973); see also Merrill Lynch, Pierce, Fenner \& Smith, Inc. v. Ware, 414 U.S. 117, 127 (1973) ("proper approach is to reconcile "the operation of both statutory schemes with one another rather tlian holding one conipletely ousted.' " (quoting Silver v. New York Stock Exchange, 373 U.S. 341, 357 (1963))).

187. Note, supra note 114, at 653; see also Wiggins, supra note 116, at 56 ("If . . . state and national power is utilized to solve different problems, the state's action slould be encouraged if the degree of overlap between the two provisions is found to be incidental to the operation of both.").

188. Pacific Gas \& Electric, 461 U.S. at 222-23; see also Commonwealth Edison Co. v. Montana, 453 U.S. 609, 633, 636 (1981) (rejecting claim that congressional policy favoring use of coal as a fuel source preempted state coal tax).

189. Silkwood v. Kerr-McGee Corp., 464 U.S. 238, 256 (1984). The finding that "[p]aying both federal fines and state-imposed punitive damages for the same incident would not appear to be physically impossible," id. at 257, apparently convinced the Court that the federal and state standards could coexist. 
in areas where Congress has already acted indicates that a state regulation supported by a legitimate state interest and only indirectly conflicting with exphicit provisions of a federal statute inay withstand a conflict preemption challenge. This conclusion should support the viability of nuclear free zones that prohibit the manufacture of nuclear weapons and weapons parts.

\section{IV}

\section{Statutory Preemption and Nuclear Free Zones}

Nuclear free zones challenge the Court's deference to state interests in nuclear inatters articulated in Pacific Gas \& Electric and Silkwood. Because nuclear free zone ordinances often are enacted as a result of strong local disagreement with national nuclear weapons policy and because ordinances may have an impact on foreign affairs, nuclear free zone ordinances require courts to reexamine a number of the Supreine Court's unsettled doctrines. Nonetlieless, the trends that culminated in Pacific Gas \& Electric and Silkwood indicate that nuclear free zones prohibiting the manufacture of nuclear weapons or nuclear weapons components can withstand a statutory preeinption challenge.

\section{A. Nuclear Free Zones Are Valid Under the Subjective Intent Test}

In employing the subjective intent test to find Congress intended to occupy the field of nuclear weapons production, a court will need to find a clear intent to preempt state law. Whether courts will find that Congress intended to occupy the field regulating the production of nuclear weapons depends upon how courts construe the text and history of the AEA. ${ }^{190}$

The United States military had absolute and secret control over the developinent of nuclear technology during World War II. ${ }^{191}$ After the war, Congress passed the Atomic Energy Act of 1946, ${ }^{192}$ which created the first legislative scheme for the civilian oversight of nuclear power developnient. Regulatory authority was embodied in a new government agency, the Atomic Energy Commission ("AEC"). ${ }^{193}$ The AEC and its adjunct, the Military Liaison Committee, focused primarily on the development of nuclear weapons. ${ }^{194}$ Although the AEA ceded the develop-

190. 42 U.S.C. $\$ \S 2011-2296$ (1988).

191. Nuclear power was originally developed during the early 1940 's by the top secret "Manhattan Project" for the primary purpose of manufacturing and using the first atomic weapons. See generally D. Ford, The Cult of the Atom: The SeCret PApers OF THE Atomic Energy Commission 25-29 (1982) (discussing early history of nuclear power program culminating in Abomb).

192. Ch. 724,60 Stat. 755 (1946) (amended 1954).

193. Id. at 756-57.

194. Id. at $756-58$. 
ment of nuclear power to civilian control, it made no reference to private commercial development of nuclear technology.

Congress then passed the Atomic Energy Act of 1954 (the "AEA"), ${ }^{195}$ which encouraged private commercial development and use of nuclear technology. The revised AEA granted the AEC, and its successor, the Nuclear Regulatory Commission ("NRC"), ${ }^{196}$ exclusive authority to license the transfer, delivery, receipt, acquisition, possession, and use of nuclear materials for both peaceful and military purposes. ${ }^{197}$ At the same time, it granted the AEC the authority to research, develop, and produce nuclear weapons on its own. ${ }^{198}$

Although the AEA also gave states substantial authority to control the peaceful use and development of nuclear power, it did not provide for similar state control over nuclear weapons. ${ }^{199}$ For imstance, the AEA made it unlawful for any person not hicensed by the NRC to produce or possess any nuclear weapons. ${ }^{200}$ Further, the AEA allowed the NRC to recapture any special nuclear material and enter any nuclear plant whenever Congress declares a state of war or national emergency. ${ }^{201}$ Thus, Congress clearly did not intend to cede to the states the right to license the production of nuclear weapons or to impede the federal government's decision to use nuclear weapons during war.

However, it is unclear whether Congress intended to require the states to permit private compamies to manufacture nuclear weapons during peacetmie. The AEA neither requires private contractors to produce nuclear weapons nor exphicitly prohibits states from regulating or limiting the private production of nuclear weapons. Thus, if a court applies a subjective intent test and looks for an exphicit directive, it will find nothing in the AEA that specifically precludes state regulation in all areas affectimg the production of nuclear weapons.

Nonetheless, opponents of nuclear free zones could argue that the AEA's exclusive grant of power to the NRC to license the development

195. Ch. 1073, § 1, 68 Stat. 919 (codified as amended at 42 U.S.C. $\S \S 2011-2296$ (1988)).

196. Congress abolished the AEC, and the Nuclear Regulatory Commission ("NRC") assumed all of its "licensing and related regulatory functions" in 1974. Atomic Energy Act of 1954, Pub. L. No. 93-438, 88 Stat. 1237, 1243 (1974) (codified as amended at 42 U.S.C. $\$ \S 5841(\mathrm{a}), 5841(\mathrm{f})$ (1988)).

197. Atomic Energy Act of 1954, ch. 1073, § 1, 68 Stat. 921, 923, 928-36 (codified as amended at 42 U.S.C. $\S \S 2014(\mathrm{e}), 2014(\mathrm{z})(2), 2014(\mathrm{aa}), 2061-2064,2071,2073-2077,2091-2099,2111-2131$ (1988)).

198. Id. at 936 (codified as amended at 42 U.S.C. $\S 2121$ (a) (1988)).

199. Atomic Energy Act of 1954, Pub. L. No. 86-373, 73 Stat. 688 (1959) (codified as amended at 42 U.S.C. § 2021 (1988)); see Pacific Gas \& Elec. Co. v. State Energy Resources Conservation \& Dev. Comm'n, 461 U.S. 190, 208-17 (1983) (Court acknowledged that AEA has always permitted states to plan power plants and set rates).

200. Atomic Energy Act of 1954, ch. 1073, §1, 68 Stat. 936 (1954) (codified as amended at 42 U.S.C. $\S 2122(1988))$.

201. Id. at 939 (codified as amended at 42 U.S.C. § 2138 (1988)). 
and production of nuclear weapons manifests Congress' intent to expand federal authority and thus occupy the field. ${ }^{202}$ Yet, in Pacific Gas \& Electric, the Court found that the NRC's exclusive authority over safety matters did not require preemption of all regulations affecting nuclear power. ${ }^{203}$ Instead, the Court drew an analytical distinction between how nuclear facilities are to be built and whether they are to be built. ${ }^{204}$ Safety conccrns aside, if a community did not need additional electrical power, the NRC was not authorized to inandate the construction of a nuclear power plant. Likewise, communities that no longer required the cconomic benefits conferred by hosting nuclear weapons production plants should be able to respectfully decline their lucrative advances.

It may be argued, however, that Congress' intent regarding nuclear weapons production is entirely different from its intent regarding the peaceful use of nuclear power. ${ }^{205}$ Accordingly, while the AEA permits states to regulate the peaceful uses of nuclear energy, the federal government has exclusive power over the regulation of nuclear weapons production. ${ }^{206}$ One commentator argued that because the AEA treats the development of nuclear weapons and nuclear power differently, the logic of Pacific Gas \& Electric and Silkwood should not apply to nuclear free zones. ${ }^{207}$

This argument, however, fails to distimguish between the AEA's treatment of the development and production of nuclear power and its treatment of the end uses. Although the AEA grants to the federal government exclusive power to regulate the possession and use of nuclear weapons, section 2121 allows the transfer of federally owned nuclear weapons teclinology "to State and local governments, private industry, and universities or other nonprofit organizations so that the prospects for

202. See Comment, supra note 33 , at $\mathbf{9 8 7 - 8 8}$ (stating that in light of legislative history there is "no reason to believe... extension of the state regulatory power over nuclear weapons manufacturers would comport with the national defense concerns which also shaped the [AEAl").

203. 461 U.S. at 211-12.

204. Id.

205. See, e.g., Borchers and Dauer, supra note 33, at 107-10 (discussing differences in AEA's treatment of nuclear weapons production and nuclear power production); Comment, supra note 33, at 985-88 (arguing that legislative history of AEA indicated Congress did not intend to extend scope of state regulation to nuclear weapons inanufacturers).

206. Borchers \& Dauer, supra note 33, at 109. Borchers and Dauer incorrectly interpreted 42 U.S.C. $\$ 2121$ (a) as granting "sole authority to do research and development work" to the NRC. Id. at 108. Section 2121(a) authorizes the NRC to conduct its research but does not prohibit the NRC from allowing private commercial enterprises to do research and development. Atomic Energy Act of 1954, 42 U.S.C. $\$ 2121$ (a) (1988). Section 2121(a)(5) empowers the federal government to license states and private entities to conduct nuclear weapons research and development and to produce nuclear weapons. 42 U.S.C.A. $\$ 2121(a)(5)$ (West Supp. 1991). Thus, while the NRC retains an "absolute Government monopoly," Borchers \& Dauer, supra note 33, at 108, over the licensiug of nuclear weapons production, the NRC can entrust the production of nuclear weapons to properly licensed private manufacturers.

207. See Borchers \& Dauer, supra note 33, at 109-10. 
commercialization of such technology are enhanced."208 Thus, once hicensed by the federal government, state universities such as the University of California nuay design nuclear weapons, and private conıpanies such as Rockwell International and Monsanto may produce plutoniunı triggers, detonators and timers for nuclear warheads. ${ }^{209}$ This hicensing scheme closely parallels the regulation of the developnient of nuclear power. Sections 2121 and 2051 both allow the federal government to cede nuclear technology and material to the states or private persons to enhance the development and production of nuclear weapons. As one commentator quite aceurately claimed, "[t]he Act's central distimction betwecn nuclear power and weapons production . . . is its radically different treatnient of the end-product of each."210 The production of nuclear energy and weapons, however, is treated similarly.

Thus, the issue is not whether communities can regulate how nuclear weapons are produced or used, but whether a community can make an economic decision to disallow the manufacture of nuclear weapons. Although the AEA may treat the end products of nuclear technology differently, ${ }^{211}$ the hicensing requirements are identical. ${ }^{212}$ The NRC's exclusive authority to decide who can build nuclear weapons does not necessarily confer the peacetime authority to decide that private contractors must build thein or that communities must allow those contractors to build thein. Given that both Pacific Gas \& Electric and Silkwood support narrow constructions of federal nuclear regulatory authority in order to accommodate legitimate state interests, ${ }^{213}$ the Court should use a similar presuniption regarding nuclear free zones.

Furtherniore, the AEA should not be interpreted too broadly even in the more sensitive context of nuclear weapons because an overly broad federal interest would disallow any material state regulation. This would create a "regulatory vacuun" where, once the NRC had licensed a private organization as a nuclear weapons producer, localities could not enact any regulation that would nuaterially affect those conipanies. ${ }^{214} \mathrm{~A}$ narrow construction of the AEA, in contrast, would preserve the balance between federal and state interests, granting exclusive licensing to the

208. 42 U.S.C.A. $\S 2121$ (a)(5) (West Supp. 1991).

209. K. Bertsch \& L. SHAw, The NUClear Weapons INDUSTRY 56, Table 9 (1984).

210. Borchers \& Dauer, supra note 33, at 108 (emphasis added).

211. For instance, the AEA makes it unlawful for any person not licensed by the NRC to produce or possess a nuclear weapon. 42 U.S.C. § 2122 (1988). The end product of the peaceful use of nuclear power is electricity, which is not similarly restricted.

212. See 42 U.S.C. $\$ \S 2133,2134$ (1988).

213. See supra text accompanying notes 171-89.

214. Cf. Foote, Regulatory Vacuums: Federalism, Deregulation and Judicial Review, 19 U.C. DAVIS L. REV. 113 (1985) (arguing deregulatiou can create a "regulatory vacuum" if states are barred from regulating $\mathrm{m}$ an area and the federal government cliooses not to regulate in that same area). 
NRC, but allowing localities to make nonlicensing decisions to further legitimate local interests. A community could legitimately decide to prohibit the manufacture of nuclear weapons for reasons entirely independent of the federal government's nuclear weapons pohicies. Indeed, following the Pacific Gas \& Electric distinction between safety and economic concerns, many localities may rely on economic concerns to justify nuclear free zone ordinances. ${ }^{215}$

Given improving relations between the Soviet Umion and the Umited States, communities may legitimately fear the economic havoc that could result from the loss of nuclear-weapons-producing industries. The prospect of a "peace dividend" may herald layoffs, dislocation of local defense-related businesses, and decreasing tax bases. ${ }^{216}$ Consequently, a decision to prohibit the manufacture of nuclear weapons may promote economic stability in communities that do not have nuclear weapons manufacturers and do not want to become dependent upon them, and in communities that are heavily dependent on nuclear weapons manufacturers. $^{217}$

By prohibiting the manufacture of nuclear weapons, states and localities would be exercising their traditional pohice powers to regulate in furtherance of econoimic welfare. Therefore, nuclear free zones should be able to survive constitutional and statutory challenges. The Supreme Court has granted great deference to local communities' land use and zoning decisions based on economic concerns. In Hawaii Housing Authority v. Midkiff, ${ }^{218}$ the Court found constitutional state legislation designed to "reduce the perceived social and economic evils" of certain

215. A nuclear free zone based on economic concerns would lie outside the federally occupied field of nuclear weapons licensing. However, a nuclear free zone based on a city's disagreement with the federal government over who should be granted a license would be impermissible: "[a] state moratorium on nuclear construction grounded in safety concerns falls squarely within the prohibited field [of safety regulation]." Pacific Gas \& Electric Co. v. State Energy Resources Conservation \& Dev, Comm'n, 461 U.S. 190, 213 (1983).

216. See Cooper, Defense Less, L.A. STYLE, Feb. 1991, at 76 (discussing decrease in military contracts as foreign relations have improved); Mann, Bush Administration Will Oppose Defense Industry Conversion Drive, Aviation WeEk AND SPACE Tech., Aug. 6, 1990, at 20 (discussing conversiou bills that would provide assistance for relocating and retraining workers in the defense industry); Castro, Biting the Bullets: Military Suppliers Scramble to Get Ready for the Defense BuildDown, TIME, Apr. 30, 1990, at 69 (discussing economic effects of defense cuts); Peace Dividends or Peace Recession, Economist, Apr. 7, 1990, at 31 (discussing economic effects of defense cuts); Litvan, Schaefer Seeks Slice of Peace Pie to Cushion Blow of Defense Cuts, The Wash. Tunes, Feb. 26, 1990, at C5 (discussing risk of economic dislocation in areas heavily dependent on defense spending); Victor, Worries for Workers, NAT'L J., Jan. 13, 1990, at 57 (discussing decline of jobs in the defense industry).

217. But see Closson, The Viability of Nuclear-Free Zones: Two Views, Bull. MUN. FOREIGN PoL'y, Spring 1988, at 46, 49-50 (surveying areas where nuclear free zone ordinances were rejected, noting citizens in those areas were concerned that prohibiting the manufacture of nuclear weapons would cause economic dislocation).

218. 467 U.S. 229 (1984). 
land use patterns. ${ }^{219}$ Although the Court has never clearly defined with precision which state interests can be protected through zoning, "[prior cases] have inade clear . . . that a broad range of governmental purposes and regulations" are valid. ${ }^{220}$ Valid interests have ranged fron scenic concerns ${ }^{221}$ to landmark preservation ${ }^{222}$ and to residential zoning. ${ }^{223}$

Nevertheless, it inay be argued that while communities may be inotivated by valid economic concerns, nuclear free zones should be preeinpted on the basis that communities are also expressing disagreenent with federal nuclear weapons policies. However, the Court has expressed its distaste for becoming "embroiled in attempting to ascertain [a state's] true inotive."224 And even assuming that communities are not permitted to enact legislation protesting the federal government's nuclear weapons policies, precedent indicates the Court may uphold a local statute provided that the locality had some legitimate purpose.

The Court has stated that where Congress does not "inanifest its intention clearly," the Court will not presunie "that a federal statute was intended to supersede the exercise of the power of the state."225 In Pacific Gas \& Electric, for example, the Court upheld an economically based state regulation that affected safety and was partially based on safety concerns, even though the AEA provided for exclusive federal authority over safety issues. ${ }^{226}$ Nuclear free zones should be treated no differently; if a locality has exercised its legitimate police powers, the Court should not strike down the regulation because an impermissible interest may have influenced an otherwise valid decision.

Thus, under the subjective intent test, the AEA does not demonstrate that Congress intended to occupy the entire field of nuclear weapons production. While Congress has granted the NRC exclusive regulatory authority over hicensing decisions, nuclear technology and the weapons themselves, it has not "clearly manifested" its intent to exclude localities from making economically based decisions that affect a private contractor's ability to manufacture nuclear weapons in a specified area.

219. Id. at 229, 243-44 (emphasis added).

220. Nollan v. California Coastal Comm'n, 483 U.S. 825, 834-35 (1987). Whether these regulations constitute takings requiring compensation is a complicated question beyond the scope of this Comment.

221. See, e.g., Agins v. Tiburon, 447 U.S. 255, 260-62 (1980) (upholding zoning ordinances that furthered city's interest in protecting residents from ill effects of urbanization).

222. Penn Cent. Transp. Co. v. New York City, 438 U.S. 104, 123-28 (1978) (holding laws that limit use of private property as landmarks do not coustitute a taking).

223. Euclid v. Ambler Realty Co., 272 U.S. 365 (1926) (upholding zoning ordinance regulating private land development).

224. Pacific Gas \& Electric Co. v. State Energy Resources Conservation \& Dev. Comm'n, 461 U.S. 190, 216 (1983).

225. New York Dep't of Social Servs. v. Dublino, 413 U.S. 405, 413 (1976) (quoting Schwartz v. Texas, 344 U.S. 199, 202-03 (1952)).

226. See supra text accompanying notes 144-52. 
Like California's nuclear reactor moratorium, nuclear free zone ordinances are rooted in traditional state police powers. As a result, the subjective intent test mandates a finding tliat nuclear free zones are not statutorily preempted.

\section{B. Nuclear Free Zones Withstand Objective Occupational Preemption Analysis}

Altliougli Silkwood and Pacific Gas \& Electric continued a trend toward favornig state interests, a court might still apply objective preemption analysis to nuclear free zones because the military's ability to procure weapons involves a strong federal interest. Consequently, even if Congress did not expressly preempt state regulation of nuclear weapons production, courts may look for other indicators of congressional intent to preempt state law, imcluding the pervasiveness of the regulation and the dominance of the federal interest.

First, because the AEA comprehensively regulates nuclear weapons production, a court could conclude tliat Congress intended to displace all local action. But in Pacific Gas \& Electric, the Court found that "[e]ven a brief perusal of the Atomic Energy Act reveals that despite its comprehensiveness, it does not at any point expressly require the States to construct . . . nuclear powerplants." 227 Nor does the AEA prohibit tlie states from "deciding, as an absolute or conditional matter, not to permit the construction of any further reactors."228 The AEA is equally silent, though just as compreliensive, on the issue of the peacetime construction of nuclear weapons. ${ }^{229}$ As a consequence, a court sliould not treat the pervasiveness of the AEA's regulation as dispositive of congressional intent to prohibit local regulation of the manufacture of nuclear weapons.

Second, a court may invalidate a state regulation by finding a dominant federal interest. ${ }^{230}$ It could find that the strong federal interests in foreign and military affairs act as the guiding principle in determining congressional intent. Because the federal government possesses such a strong interest in national defense, a court could conclude that congressional control over that field was meant to be exclusive. ${ }^{231}$ Indeed, in Boyle v. United Technologies Corp., ${ }^{232}$ the Court immumized defense contractors from products liability by creating in the federal government, in the absence of any statute, a " 'uniquely federal' interest" in "tlie pro-

227. 461 U.S. at 205 (emphasis added).

228. Id.

229. See supra text accompanying notes 208-10.

230. Rice v. Santa Fe Elevator Corp., 331 U.S. 218, 230 (1947). See supra text accompanying notes 117-19.

231. See, e.g., cases discussed supra Part II(A).

232. 487 U.S. 500 (1988). 
curement of equipment."233 Challengers to nuclear free zones may argue that since restrictions on nuclear weapons production clearly affect the federal government's ability to procure weapons, nuclear free zones impermissibly infringe upon this mterest.

However, Boyle limited its holding and thus the federal interest in nuclear weapons procurement. Boyle did not create an absolute immunity for federal defense contractors, but rather a limited immunity that protected the government's discretion to design and order specific weapons. ${ }^{234}$ And it created this new and controversial law by manufacturing a preemptive federal interest in the absence of a federal statute. ${ }^{235}$ Unlike defense contractor hability, however, nuclear weapons are comprehensively governed by a federal act, the AEA. It therefore would be odd to create a "uniquely federal interest" in nuclear weapons production and procurement beyond that established by the governing statute as part of a statutory preeniption analysis. ${ }^{236}$

Finally, even assuming there is a dominant federal interest in national defense, it is unclear whether all state actions affecting national defense impermissibly intrude on that interest. The issue then becomes to what extent a state's action may affect foreigu affairs or national defense before it will be preempted. In Hines v. Davidowitz, ${ }^{237}$ Justice Stone wrote:

Little aid can be derived from the vague and illusory but often repeated formula that Congress "by occupying the field" has excluded from it all state legislation. Every Act of Congress occupies some field, but we must know the boundaries of that field before we can say that it has precluded a state from the exercise of any power reserved to it by the Constitution. ${ }^{238}$

Defining federal boundaries necessarily entails defining state boundaries as well. Thus, where the federal interest is permeable, determining the parameters of the oceupied field involves not only determining what Congress intended, but also the impact of the state action. Because it focuses on the state action, the dominant federal interest test is indistingnishable from the conflict preeniption analysis discussed below.

233. Id. at 504-06.

234. See supra text accompanying notes 65-69 (discussing Boyle).

235. 487 U.S. at 504; see also id. at 515-16 (Brennan, J., dissenting) (criticizing majority's immunization of defense contractors from liability for government-approved projects).

236. For a discussion of the distinction between the exclusive federal interest in nuclear safety and local economically based decisions nnder the AEA, see supra Part III(A).

237. 312 U.S. 52 (1941).

238. Id. at 78 (Stone, J., dissenting). 


\section{Nuclear Free Zones Do Not Conflict with Federal Policies}

The AEA does not grant to private defense contractors a federally protected right to manufacture nuclear weapons. Thus, it is difficult to conceive of a situation where a nuclear free zone prohibiting the manufacture of nuclear weapons would necessarily conflict with the provisions of the AEA. However, a state law may still be preempted if it "stands as an obstacle to the accomphishment and execution of the full purposes and objectives of Congress."239 Arguably, nuclear free zone ordinances obstruct Congress' objective to manufacture and stockpile nuclear weapons. Because nuclear free zones prohibit the manufacture of nuclear weapons, they eliminate potential sources of nuclear weapons. And if every community were to enact such legislation, such ordinances would "impair[ the efficiency, if . . . not utterly destroy"240 the federal government's ability to conduct national defense.

It is important to note, however, that a properly constructed nuclear free zone, like the model proposed in this Comment, ${ }^{241}$ would not attempt to regulate the federal government dircctly. Nor would it attempt to regulate the military or activities on military bases or federal property. It would only affect private defense contractors. Consequently, the issue becomes what degree of conflict with the private manufacture of nuclear weapons Congress intended to tolerate.

Congress' decision to dissolve the federal monopoly of nuclear power informs this question. As with the peaceful uses of nuclear power, the AEA authorized the NRC to license private commercial enterprises to manufacture nuclear weapons. ${ }^{242}$ Entrusting the production of essential weapons components to private companies indicates that Congress did not fear peacetime shortages. Private defense contractors are subject to a nuniber of economic and legal pressures. These problems include labor, economic competition, state and local taxation, and other freemarket influences. These factors create the possibility that a nuclear weapons manufacturer may find itself overtaxed, facing a strike, no longer competitive, or inerely unprofitable. This could force a manufacturer simply to dissolve. The consequence, of course, would involve a halt in the production of nuclear weapons. Nevertheless, Congress judged that free-market participants would be the most efficient developers and producers of nuclear weapons.

If Congress had intended to develop nuclear weapons "at all

239. Id. at 67 (citation omitted).

240. Tarble's Case, 80 U.S. 397, 408 (1871).

241. See supra text accompanying note 20.

242. 42 U.S.C.A. § 2121(a)(5) (West Supp. 1991). 
costs, ${ }^{243}$ and with no possibility of interference, it would not have dismantled the federal nuclear monopoly. Although developing nuclear weapons through a federal agency might be less economically efficient than the private inanufacture of these weapons, federal agencies face fewer economic and legal pressures than private coinpanies. Further, Congress could have expressly exempted nuclear inanufacturers from all local regulations and taxes. Congress did neither, which indicates that, like the development of nuclear power, the developinent of nuclear weapons is not to be exempted from all state regulation.

But a nuclear free zone could still conflict with the AEA if it imposed too high a cost. For exaniple, if every comnnunity decided to prohibit the production of nuclear weapons, no weapons would be produced and the cost would be unbearable. ${ }^{244}$ This doinestic domino theory, however, is untenable for two reasons. First, it is unlikely that nuclear free zones will have anything but a "speculative and indirect impact"245 on the production of nuclear weapons. Not every comınunity will enact a nuclear free zone ordinance. Although inany cominunities enact nuclear free zones because they disagree with federal nuclear weapons policy or fear the economic consequences of "peace dividends," many others reject proposed nuclear free zone legislation because citizens fear the economic dislocation caused by prohibiting the manufacture of nuclear weapons. ${ }^{246}$ In addition, the federal government can create economic incentives beyond those already employed should it fear a lack of supphiers. The promise of federal money almost invariably persuades localities to do Congress' bidding.

Second, even if every community in the United States prohibited the manufacture of nuclear weapons, federal facilities could produce nuclear weapons. ${ }^{247}$ These facilities, now operated by private or state contractors under the direction of the Departinent of Energy and the Departinent of Defense, include five laboratories, seven production and testing facilities, four nuclear material production facilities, and three other weapons-

243. Pacific Gas \& Electric Co. v. State Energy Resources Conservation \& Dev. Comm'n, 461 U.S. 190, 222 (1983).

244. Cf. Fossella v. Dinkins, 110 A.D.2d 227, 229-30, 494 N.Y.S.2d 878, 880 (App. Div.) (finding proposed ordinance prohibiting city aid to a federal military installation unconstitutional because if every local government did likcwise, the federal government's power to raise and support an army would be destroyed), aff'd, 66 N.Y.2d 162, 485 N.E.2d 1017, 495 N.Y.S.2d 352 (1985).

245. Arthur D. Little, Inc. v. Commissioner of Health and Hosps. of Cambridge, 395 Mass. 535, 547, 481 N.E.2d 441, 449 (1985) (quoting De Canas v. Bica, 424 U.S. 351, 355 (1976)).

246. See Closson, supra note 217 , at $46,49-50$.

247. See 42 U.S.C. $\S 2121$ (a) (1988). Cf. Arthur D. Little, 395 Mass. at 548, 481 N.E.2d at 449 (1985) (citing McQueary v. Laird, 449 F.2d 608, 612 (10th Cir. 1971)) (recognizing that even if every community prohibited production of chemical warfare agents within their city limits, the Department of Defense could conduct chemical warfare research on its bases because the federal government has unfettered control with respect to internal inanagement and operation of federal military establishments). 
related facilities. ${ }^{248}$

Finally, the federal government is authorized under the AEA to reclaim all nuclear inaterials and technology. Section 2121(b) of the AEA permits the federal government to reestablish, during peacetime, its nuclear monopoly. ${ }^{249}$ That such an option exists under the AEA indicates that Congress anticipated possible obstructions to the private manufacture of nuclear weapons. These obstructions probably included the market forces discussed above, but may have also included local obstacles such as prohibitively high tax rates or restrictive zoning ordinances.

An economically based nuclear free zone is no different froin a zoning ordinance forbidding the production of nuclear materials next to a school. Both are permissible as an exercise of traditional local police powers. ${ }^{250}$ Section 2121 manifests Congress' acceptance of this division of regulatory authority.

Thus, nuclear free zones do not expressly conflict with the terms of the AEA. Further, they do not obstruct congressional purposes regarding the manufacture of nuclear weapons. Because the construction of nuclear weapons was not to be accomplished "at all costs," and because nuclear free zones do not imipose "too high a cost," local regulatory efforts to prohibit the production of nuclear weapons should survive conflict preeinption analysis.

V

\section{CONCLUSTON}

This Comment has attempted to demonstrate that state and local governments that ban the manufacture of nuclear weapons and nuclear weapons parts under their traditional pohce powers will not be constitutionally or statutorily preenpted. This thesis depends upon three propositions. First, the Constitution alone does not prohibit nuclear free zones. Despite the federal government's exclusive authority over national defense, not every state or local action that affects this interest is unconstitutional. Second, in enacting the AEA, Congress did not intend to occupy the entire field of nuclear weapons production. The AEA left to states and localities the ability to make decisions about their own economic survival. Third, nuclear free zones do not conflict with federal statutes or obstruct federal purposes. Because the AEA does not require the inanufacture of nuclear weapons "at all costs," and because nuclear free zones do not impose unacceptable costs on the production of nuclear

248. K. BERTSCH \& L. SHAW, supra note 209, at 55-63.

249. 42 U.S.C. $\S 2121$ (b) (1988).

250. See supra text accompanying notes 218-23. 
weapons, their impact on federal national defense pohicy does not require invalidation.

With respect to the first contention, the Court has not read the Constitution as an absolute bar to any state action that affects foreign affairs. Although the Court has at times relied on a "dormant foreign affairs" power, this quasi-doctrine has not enjoyed universal application. Where the state action's effect on foreign affairs is indirect, as is the case with nuclear free zones, the Court lias allowed it.

Furtler, the evolution of the Court's preenption doctrine has increasingly favored state interests. This presumption reflects the Court's conception of the balance between state and federal initerests. The Court's view of federalisn discourages it froin creating a federal interest in foreign affairs so broad that it invalidates any state action that in any way affects this field. As a result, the federal interest in national defense does not create an absolute bar to state and local action.

The second proposition depends upon the Court's interpretation of the AEA in Pacific Gas \& Electric and Silkwood. Botl cases favored state interests by requiring that Congress inake clear its intent to preenipt state action in the field of nuclear weapons production. Although Congress in both cases inade its intentions clear in the area of nuclear safety and the licensing of nuclear technology, econormic niatters of local concern were left to local control. Further, because the AEA treats the licensing of nuclear weapons manufacture identically to the licensing of peaceful uses of nuclear energy, there is no reason to treat the two fields differently with respect to congressional intent.

The last proposition also depends upon the Court's decisions in Pacific Gas \& Electric and Silkwood. The Court in both cases found that the developnient of nuclear technology was not intended to proceed at all costs. As a result, the issue becoines whether nuclear free zones innose too high a cost. Two facts indicate they do not. First, it is unlikely that every community will enact nuclear free zones. Second, even if every commumity in the United States adopted a nuclear free zone, the NRC could still continue research, developnent, and production in its own facilities.

Finally, nuclear free zones involve central questions about federalisn. At issue is whether, in the absence of clear congressional intent, the Court can supply this intent to preeinpt and thereby preclude state action. Because the Court has recently reeniphasized its preference for state interests, this Comment concludes that localities are free to exercise their police powers and prohibit the inanufacture of nuclear weapons within their borders. 